\title{
Effect Maltodextrin on Hedonic Attributes of Tray-Dried Fish Gelatin Powder from Bone of Pangasius sp.
}

\author{
Josua Wanson Pakpahan", Yoni Atma ${ }^{\#^{*}}$ \\ \# Department of Food Science and Technology, Faculty of Bioindustry, Universitas Trilogi, Kalibata, Jakarta 12760, Indonesia \\ *Corresponding author,e-mail: yoniatma@trilogi.ac.id
}

\begin{abstract}
This research aims to drying liquid gelatin from bone of pangasius sp. through maltodexrtrin addition by using tray dehydrator. The stages of this study were including fish bone gelatin extraction and drying of liquid gelatin at $55^{\circ} \mathrm{C}$ for 6 hours coupled with addition of maltodextrin $(0 \%, 5 \%, 8 \%, 11 \%$, and $14 \%)$. The analysis covering gelatin yield and organoleptic parameter i.e hedonic test toward color, aroma, texture, and overall preference. Then, proximate analysis was done also on the selected dried fish bone gelatin. The results shown that maltodextrin addition has significant effect to the hedonic attributes of resulting fish bone gelatin powder by tray drying process. The panelists preference toward fish bone gelatin powder with maltodextrin is like slightly whether to color, aroma, texture, and overall appearance. The yield of dried fish bone gelatin using tray dehydrator is about 16\%. The moisture, ash, protein and fat compositions of dried fish bone gelatin in this study were $11.45 \%, 0.96 \%, 36.15 \%$, and $0.045 \%$ respectively.
\end{abstract}

Keywords—drying; fish gelatin; halal gelatin; maltodextrin; organoleptic

\section{INTRODUCTION}

Gelatin has been used in diverse industries such as food, pharmaceutical, cosmetics and photography industries. Mostly, gelatin derived from mammalian skin and bone. Yet, research about alternative source of gelatin blowing up in the last decade. The alternative sources of gelatin including from insects, chicken feet fish skin and fish bone. Bone of fish is one alternative sources for gelatin production. Among bone of fish, it was confirmed that one potential as source of gelatin coming from Pangasius catfish. Pangasius catfish (or in Indonesia called Patin) is one superior commodities in fishery industries and local markets. Ministry of Fisheries and Marine Affairs projected the production of this type of fresh water fish is increase continuously [1]. As a result, it would be implicated to their waste, particularly the fish bone. Research conducted by Mahmoodani et al. (2014) showed that Pangasius catfish bone gelatin has physical qualities which comparable to cow-based gelatin [2]. A study conducted by Pertiwi et al. (2018) and Atma et al. (2018) showed that moisture content of gelatin from Pangasius catfish bones confirmed with standards gelatin. Where, moisture content is one of the important chemical quality parameters of gelatin powder [3][4].

Unfortunately, most previous studies about gelatin from bone of Pangasius catfish only produced gelatin in a form of liquid gelatin, even though gelatin in liquid form has many drawbacks such as short shelf-life or easily contaminated (related water content) as well as vulnerable to spill out during storage and transporting process. Therefore, it is need to evaporate the liquid fish bone gelatin to become a powder. One method that can be used in drying gelatin is a tray type food dehydrator. Drying using tray dehydrator is simply and inexpensive. However, they are potentially ruin the gelatin due to time consuming, while gelatin is a protein which sensitive on heat process or high temperature. So that, it is required a coating ingredient such as maltodextrin to protect the gelatin from heat denaturation. Despite this polysaccharide also has another role such as preventing browning non-enzymatic and increasing the yield of gelatin powder. Maltodextrin is effective for protecting materials from oxidation. Maltodextrin has unique characteristics like being soluble in cold water, disperse rapidly, high solubility [5].

Nevertheless, maltodextrin could be also affecting the organoleptic and chemical properties of encapsulated or dried product like gelatin powder [6]. Whilst, these two parameters are essential in order to producing gelatin powder. Therefore, it is necessary to study the effect of maltodextrin utilization in organoleptic and chemical composition of the gelatin powder dried with tray dehydrator as prior analysis before fish bone gelatin applied as raw material which will be offer to the potential consumers.

\section{MATERIAL AND METHODS}

This study was conducted in four stages covering fish bone gelatin drying, organoleptic test, data analysis and proximate analysis on selected fish bone gelatin. 


\section{A. Fish bone gelatin drying}

Liquid solution of fish bone gelatin had extracted on previous study conducted by Pertiwi et al. (2018) [3]. Then, this gelatin stirred at $100 \mathrm{rpm}$ followed by maltodextrin addition at various concentration $(\mathrm{m} / \mathrm{v})$ i.e $0 \%, 5 \%, 8 \%, 11 \%$ and $14 \%$. After that, the mixed solutions were poured into trays and dried at $55{ }^{\circ} \mathrm{C}$ for 6 hours. Maltodextrin concentration had selected based on protein content of most commercial gelatin $( \pm 86 \%)$ minus $100 \%$. Whilst, drying temperature considered toward study which was mentioned that drying gelatin should around $40-80{ }^{\circ} \mathrm{C}$, because gelatin usually unstable in temperature more than $80^{\circ} \mathrm{C}$ [7]. The dried gelatin quantified for their yield and stored before further analysis.

\section{B. Hedonic test}

Organoleptic analysis was done through hedonic preferences by $25 \mathrm{semi}$ trained-panel. The attributes of hedonic test including color, aroma, texture and overall appearance. Samples were given in different codes and then panelists were asked to rate from dislike (lowest point), neutral (mean point), as well as like (highest point) [8].

\section{Proximate analysis}

Sample from hedonic test with highest value of preferences was selected to proximate analysis. Proximate analysis carried based on AOAC procedures which covering moisture content, ash, protein, fat and carbohydrate (by different) [9].

\section{Data Analysis}

Data was analyzed by one-way analysis of variance (ANOVA) and continued with Duncan's Multiple Range Test (DMRT) $(\mathrm{p}<.0 .05)$ for determining significant different between data.

\section{RESUlT AND DiSCUSSION}

\section{A. Dried fish bone gelatin}

According to Ward \& Courts (1997), gelatin drying should carried out at temperature of $40-80{ }^{\circ} \mathrm{C}$ and no more than $80{ }^{\circ} \mathrm{C}$ because gelatin could be degraded at $80{ }^{\circ} \mathrm{C}$ [7]. Based on Tormando's (2006) research, the best evaporation temperature for gelatin was at $55^{\circ} \mathrm{C}$ and the drying time is around 6 hours [10]. So that, in this research we also used the same drying temperature and time. During drying process using tray dehydrator, it was produced sheet-form gelatin. Thus, the sheets were crushed and sieved to collect gelatin powder.

The yield of dried gelatin is percentage of gelatin powder divided liquid form of gelatin before drying. The yield of gelatin powder in this research around 1.45-15.95\% depends on maltodextrin concentrations which added. In this study, shown that maltodextrin addition has an effect toward gelatin yield. Figure 1 presents the yield of fish gelatin powder by tray drying treatment. Fish gelatin which greater maltodextrin concentration resulting higher gelatin yield. It is supporting the statement that maltodextrin has a role as total solid enhancer and improve powder appearance [11].

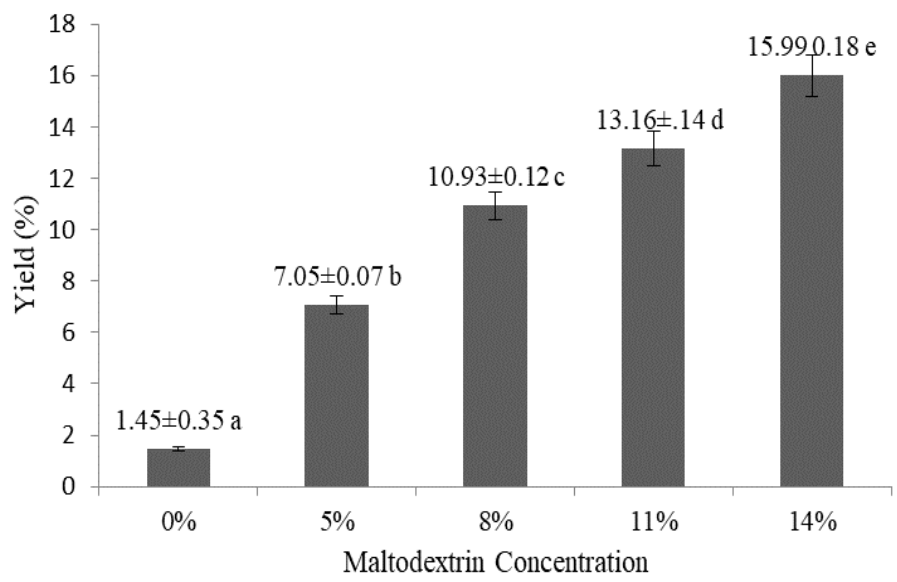

Fig. 1 Yield of dried fish bone gelatin with different maltodextrin concentration. Bars with different letters are significantly different at $\mathrm{p}<$ 0.05 .

\section{B. Color}

Color is one of the important attributes influencing consumers in choosing food. In this study, maltodextrin was influencing the color of dried fish bone gelatin. The preference of panelists is better on dried gelatin by maltodextrin inclusion. Dried fish gelatin with maltodextrin is like slightly by the panelists, while dried gelatin without maltodextrin was slightly dislike. Further analysis shown that color of dried fish gelatin with maltodextrin addition relatively no significant each other. According to Jufri (2004) maltodextrin has less browning effect [12], Supriyadi \& Rujita (2013) stated that maltodextrin has an ability to inhibit oxidation reactions [13], so it could maintain the color of gelatin powder during drying process. Figure 2 shows the score of hedonic toward color of dried fish gelatin with and without maltodextrin inclusion.

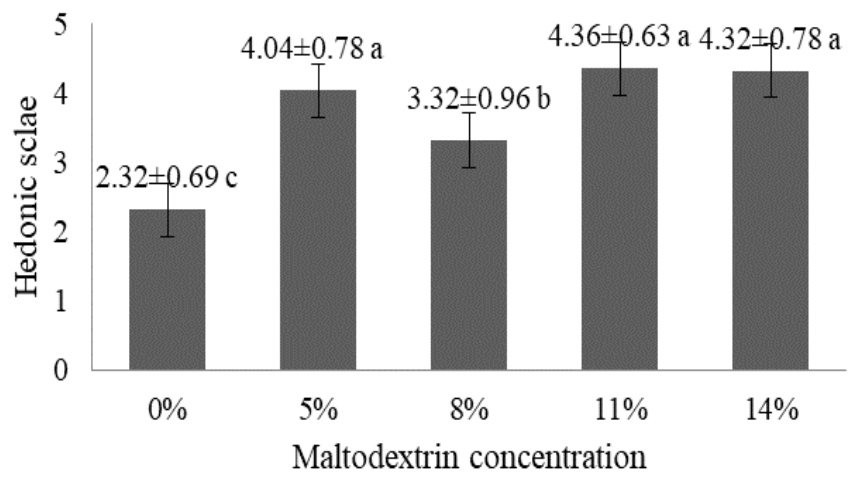

Fig. 2 Hedonic test results on color of dried gelatin. Hedonic scale; 
1=dislike, $2=$ slightly dislike, $3=$ neutral (nor dislike or like, $4=$ slightly like, $5=$ like. Bars with different letters are significantly different at $\mathrm{p}<0.05$.

\section{Aroma}

Testing on aroma in food industries is highly required in both raw material and ingredients. Aroma also can be simply identified by smelling through nose and it is giving quick results as well as sometimes capable in detecting food deteriorations [14]. Aroma of dried fish bone gelatin in this study was tested based on hedonic scale. It was found that maltodextrin addition affected to aroma of gelatin powder in term of the panelist preference. Hedonic score of dried fish bone gelatin with maltodextrin was 3.52-4.00 means the panels were like slightly on gelatin powder. While, the panelist preference on dried fish bone gelatin without maltodextrin was tend to neutral (nor like or dislike). According to panelists, addition of maltodextrin in producing fish bone gelatin powder was reducing fishy smell of dried gelatin. Figure 3 presents the dried fish bone gelatin with different maltodextrin concentrations

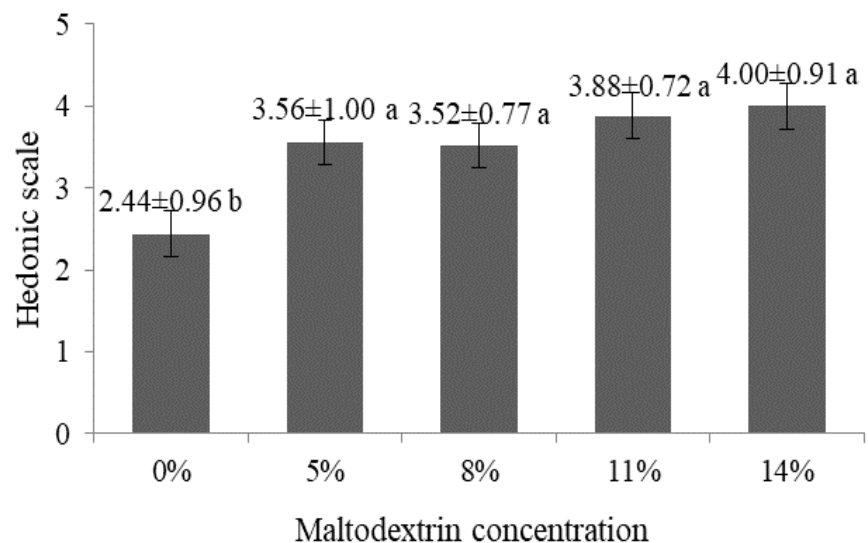

Fig. 3 Hedonic test results on aroma of dried gelatin. Hedonic scale; $1=$ dislike, $2=$ slightly dislike, $3=$ neutral (nor dislike or like, $4=$ slightly like, $5=$ like. Bars with different letters are significantly different at $\mathrm{p}<$ 0.05 .

\section{Texture}

Texture is a characteristic that represent the physical condition of food ingredients or products [15]. This study also testing the texture preference (hedonic test) of semi trainedpanelists toward dried fish gelatin with or without maltodextrin addition. Based on statistical analysis, the maltodextrin has effect on texture preference of gelatin powder. Texture of fish bone gelatin powder without maltodextrin is dislike slightly by the panel participants. While, texture with $5 \%$ and $8 \%$ maltodextrin addition are relatively neutral (nor like or dislike). Furthermore, panelists tend to like slightly on texture fish bone gelatin powder with $11 \%$ and $14 \%$ maltodextrin addition. It is concluded that maltodextrin improve the panelists preference to fish bone gelatin powder. Figure 4 shows the hedonic test result of texture attribute on fish bone gelatin powder.

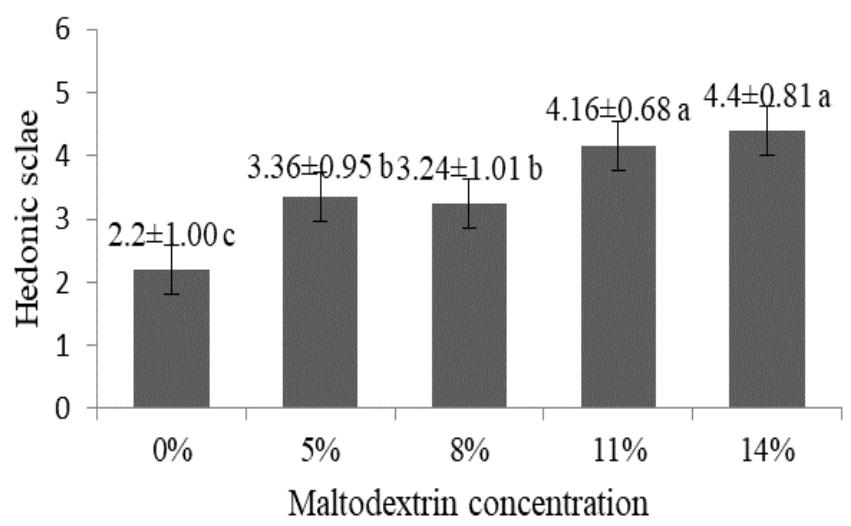

Fig. 4 Hedonic test results on texture of dried gelatin. Hedonic scale; 1=dislike, $2=$ slightly dislike, $3=$ neutral (nor dislike or like, $4=$ slightly like, $5=$ like. Bars with different letters are significantly different at $\mathrm{p}<0.05$.

\section{E. Overall appearance}

The overall appearance was used in hedonic test to measure the level of panelist preference that represents combination attributes such as color, aroma, texture and other attributes based on panelists experience during the test. In this study, the panelists are dislike slightly on fish bone gelatin powder without maltodextrin and like slightly on dried gelatin with maltodextrin addition. The addition of maltodextrin is stimulating panelists preference on fish bone gelatin powder. Figure 5 represents the hedonic test result of overall appearance on fish bone gelatin powder from Pangsius sp.

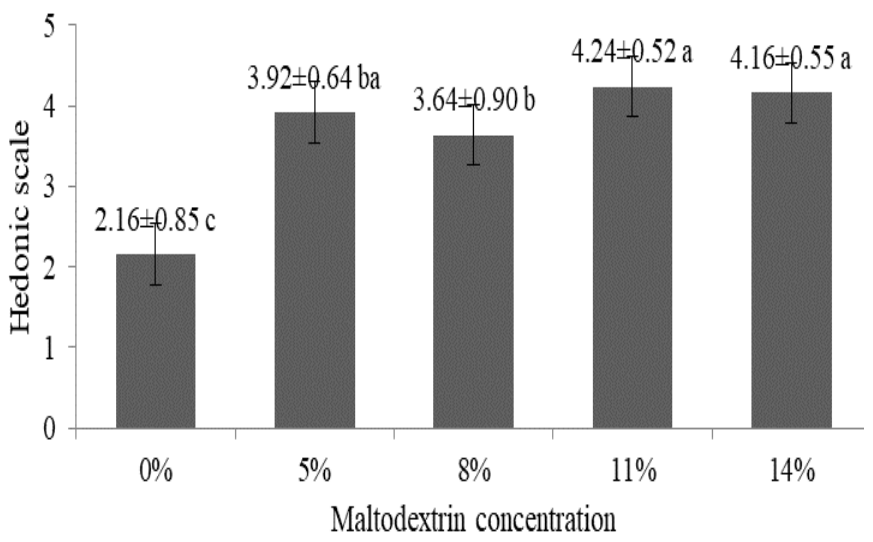

Fig. 5 Hedonic test results on overall appearance of dried gelatin. Hedonic scale; $1=$ dislike, $2=$ slightly dislike, $3=$ neutral (nor dislike or like, 4=slightly like, 5=like. Bars with different letters are significantly different at $\mathrm{p}<0.05$. 


\section{F. Proximate composition}

Analysis proximate was only carried out toward selected treatment on producing fish bone gelatin powder. The selected sample is fish bone gelatin with $14 \%$ maltodextrin addition during drying process. It is based on hedonic test results and the gelatin yield. This selected gelatin has gelatin yield higher compared to other treatments. Figure 6 presents the selected fish bone gelatin powder.

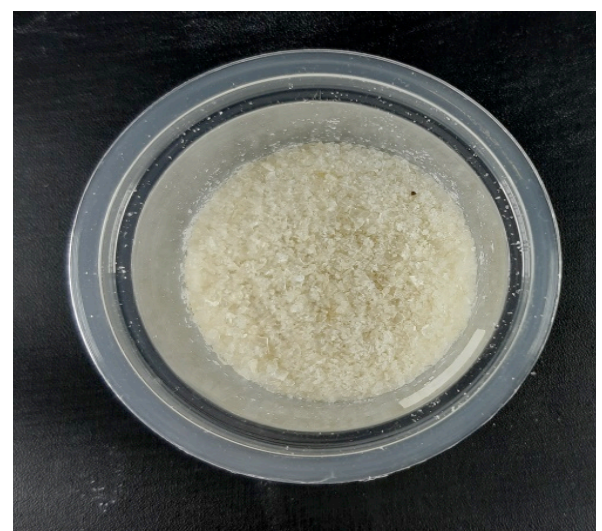

Fig. 6 Tray-dried fish bone gelatin from bone of Pangsius sp. with addition of $14 \%$ maltodextrin

Based on table 1, the dried fish bone gelatin with $14 \%$ maltodextrin has water, ash, and lipid composition which confirmed with Indonesian National Standard (SNI). These parameters are also meet the standard of commercial gelatin particularly for moisture and ash contents. However, the protein content of dried fish bone gelatin in this study was lower than commercial gelatin. So that, it is essential needed to improve the protein content of the dried fish bone gelatin in the future, although there is no standard or regulation which mention about minimal protein concentration in gelatin. Nevertheless, we generally accepted that gelatin is a protein, therefore, logically their higher composition showing their purity.

TABLE I

PROXIMATE COMPOSITION

\begin{tabular}{lrrr}
\hline $\begin{array}{c}\text { Parameters } \\
(\%)\end{array}$ & $\begin{array}{c}\text { Tray-dried Fish } \\
\text { Bone Gelatin }\end{array}$ & SNI [16] & $\begin{array}{r}\text { Commercial } \\
\text { Gelatin [17] }\end{array}$ \\
\hline Moisture & 11.45 & Maks. 16 & Maks. 15 \\
\hline Ash & 0.96 & Maks. 3.52 & Maks. 2.6 \\
\hline Protein & 36.15 & 90 & $86.1^{*}$ \\
\hline Fat & 0.045 & - & - \\
\hline Carbohydrate & 51.39 & - & - \\
\hline
\end{tabular}

*Chuaynukul et al. (2014) [18]

\section{CONCLUSION}

The maltodextrin addition has significant effect to the hedonic attributes of resulting fish bone gelatin powder by tray drying process. The panelists preference toward fish bone gelatin powder with maltodextrin is like slightly whether to color, aroma, texture, and overall appearance. The yield of dried fish bone gelatin using tray dehydrator is about $16 \%$. The moisture, ash, protein and lipid compositions of dried fish bone gelatin in this study are $11.45 \%, 0.96 \%, 36.15 \%$, and $0.045 \%$ respectively.

\section{REFERENCES}

[1] Anonim, "Optimisme Patin Indonesia Kuasai Pasar Lokal dan Dunia Menguak pada Forum Bisnis Perikanan," Kementrian Kelautan dan Perikanan, 2018. https://kkp.go.id/djpdspkp/artikel/3227-optimisme-patinindonesia-kuasai-pasar-lokal-dan-dunia-menguak-padaforum-bisnis-perikanan (accessed Oct. 20, 2019).

[2] F. Mahmoodani, V. S. Ardekani, S. F. See, S. M. Yusop, and A. S. Babji, "Optimization and physical properties of gelatin extracted from pangasius catfish (Pangasius sutchi) bone," $J$. Food Sci. Technol., vol. 51, no. 11, pp. 3104-3113, 2014, doi: 10.1007/s13197-012-0816-7.

[3] M. Pertiwi, Y. Atma, A. Z. Mustopa, and R. Maisarah, "Karakteristik fisik dan kimia gelatin dari tulang ikan patin dengan pre- treatment asam sitrat," J. Apl. Teknol. Pangan, vol. 7, no. 2, pp. 83-91, 2018.

[4] Y. Atma, H. Ramdhani, A. Z. Mustopa, M. Pertiwi, and R. Maisarah, "Karakteristik Fisikokimia Gelatin Tulang Ikan Patin (Pangasius sutchi) Hasil Ekstraksi Menggunakan Limbah Buah Nanas (Ananas comosus)," Agritech, vol. 38, no. 1 , p. 56, 2018, doi: 10.22146/agritech.29821.

[5] E. Srihari, S. F. Lingganingrum, R. Hervita, and H. S. Wijaya, "Pengaruh Penambahan Maltodekstrin pada Pembuatan Santan Kelapa Bubuk," in Seminar Rekayasa Kimia Dan Proses, 2010, p. 18.

[6] T. Mahendran, "Physico-chemical properties and sensory characteristics of dehydrated guava concentrate: effect of drying method and maltodextrin concentration," Trop. Agric. Res. Ext., vol. 13, no. 2, pp. 48-54, 2010, doi: 10.4038/tare.v13i2.3138.

[7] A. Simon, L. Vandanjon, G. Levesque, and P. Bourseau, "Concentration and desalination of fish gelatin by ultrafiltration and continuous diafiltration processes," Desalination, vol. 144, pp. 313-318, 2002, doi: 10.1016/S0011-9164(02)00333-8.

[8] A. Pop, S. Muste, V. Muresan, L. Salanta, and C. Rosa, "Studies on valorification of hot pepper powder in the technology of jelly candy products," Bull. UASVM Food Sci. Technol., vol. 71, no. 2, pp. 223-224, 2014, doi: 10.15835/buasvmen-fst.

[9] R. L. Bradley, Food Analysis, 4th ed. New York: Springer, 2010.

[10] T. Joharman, "Studi Pengaruh Suhu dan Lama Evaporasi Pada Proses Pemekatan Gelatin," Institut Pertanian Bogor, 2006.

[11] R. Heldyana, "Karakteristik Fisikokimia dan Organoleptik Tepung Mocaf (Modified Cassava Flour) dengan Perendaman Bakteri Asam Laktat Lactobacillus sp,” Universitas Trilogi, 2017.

[12] M. Jufri, E. Anwar, and J. Djajadisastra, "Pembuatan niosom berbasis maltodekstrin DE 5-10 dari pati singkong (Manihot utilissima)," Maj. Ilmu Kefarmasian, vol. 1, no. 1, pp. 1020, 2004, doi: 10.7454/psr.v1i1.3365. 
[13] Supriyadi and A. S. Rujita, "Karakteristik mikrokapsul minyak atsiri lengkuas dengan maltodekstrin sebagai enkapsulan," J. Teknol. dan Ind. Pangan, vol. 24, no. 2, pp. 201-208, 2013, doi: 10.6066/jtip.2013.24.2.201.

[14] L. Sánchez-Rodríguez et al., "Flavors and Aromas," in Chemical Deterioration and Physical Instability of Food and Beverages, no. 1, L. H. Skibsted, J. Risbo, and M. L. Andersen, Eds. Cambrige: Elsevier Inc., 2019, pp. 1-824.

[15] A. Engelen, "Analisis kekerasan, kadar air, warna dan sifat sensori pada pembuatan keripik daun kelor," J. Agritech Sci., vol. 2, no. 1, pp. 10-15, 2018.
[16] BSN, SNI 06-3735-1995: Mutu dan Cara Uji GelatinMutu dan Cara Uji Gelatin. Indonesia: Badan Standarisasi Nasional, 1995.

[17] GMIA, "Standard testing methods for edible gelatin," 2013. doi: $10.1021 / \mathrm{ja} 02055 \mathrm{a} 023$.

[18] K. Chuaynukul, T. Prodpran, and S. Benjakul, "Properties of thermo-compression molded bovine and fish gelatin films as influenced by resin preparation condition," Int. Food Res. J., vol. 22 , no. 3, pp. 1095-1102, 2015. 